\title{
A REESCRITA DOS MITOS BÍBLICOS EM JOSÉ SARAMAGO: A RE- HISTORIZAÇÃO DO SAGRADO A PARTIR DA FICÇÃO
}

\author{
Francisca Carolina Lima da Silva ${ }^{1}$
}

\begin{abstract}
RESUMO: Uma das temáticas predominantes na obra de José Saramago é a releitura e a intertextualidade com a história e com os mitos fundadores do ideário ocidental. Essa prática se constrói a partir de uma desconstrução dos textos com os quais as obras dialogam, por meio do uso da paródia, da metaficção historiográfica e da alegoria. Nesses textos, Saramago, ao mesmo tempo em que questiona crenças inabaláveis, apresenta-nos a desmistificação da História oficial, oportunizando, assim, o emanar das histórias silenciadas, a partir daquilo que poderia ter sido. $\mathrm{O}$ presente artigo pretende analisar o processo de releitura que o autor realiza na obra $O$ Evangelho segundo Jesus Cristo (2005), ao utilizar como fonte as ruínas históricas deixadas pela leitura dogmática do Novo Testamento do Judaísmo Cristão. Para tanto, faremos uso da teoria moderna da alegoria desenvolvida por Walter Benjamin, com amparo nos preceitos da Literatura Comparada, a partir do dialogismo bakhtiniano que o texto de Saramago constrói, não só com as versões canônicas dos textos bíblicos, mas também com os escritos apócrifos, também utilizando dados da história e da cultura moderna.
\end{abstract}

Palavras-Chave: Releitura; Metaficção historiográfica; dialogismo; dessacralização.

\section{THE RE-WRITTEN OF THE BIBLICAL MYTHS IN JOSÉ SARAMAGO: THE RE-HISTORIZATION OF THE SACRED FROM THE FICTION}

\begin{abstract}
One of the predominant themes in José Saramago's work is the re - reading and intertextuality with the history and the founding myths of the Western ideology. This practice is constructed from a deconstruction of the texts with which the works dialogue, through the use of parody, historiographic metafiction, and allegory. In these texts, Saramago, while questioning unshakeable beliefs, presents us with the demystification of official History, thus giving the emanation of silenced histories, from what could have been. This article intends to analyze the process of rereading the author in O Evangelho segundo Jesus Cristo (2005) performs, when using as a source the historical ruins left by the dogmatic reading of the New Testament of Christian Judaism. To do so, we will use the modern theory of allegory developed by Walter Benjamin, based on the precepts of Comparative Literature, from the Bakhtinian dialogism that Saramago's text constructs not only with the canonical versions of the biblical texts but also with the apocryphal writings, as well as data from history and modern culture.
\end{abstract}

Keywords: Re-reading; Historiographical metafiction; dialogism; desacralization.

O autor português José de Sousa Saramago, considerado um dos mais principais escritores da era contemporânea, possui em sua obra traços distintivos que constituem uma estilística inusitada e ímpar. Além disso, o lusitano é um incansável patriota, já que traz em seu espírito de escritor e de cidadão uma preocupação latente com os rumos de seu país,

\footnotetext{
${ }^{1}$ Docente da Universidade Regional do Cariri (URCA); Mestre em Literatura comparada pela Universidade Federal do Ceará (UFC); Doutoranda em Letras pela Universidade Federal do Ceará (UFC).
} 
procurando refletir, através de sua obra literária e jornalística, a configuração histórica e contemporânea de sua terra natal.

Nesse sentido, contaminado pela sensibilização oriunda do processo de silenciamento social e cultural promovido pelo governo ditatorial português, e pela insistência por parte da cultura nacional em conservar um passado tradicional pautado em mitos, Saramago se posta à tarefa de recontar as histórias esquecidas e segredadas pelo discurso oficial da história tradicional que permeiam a fundação de seu país. Isso se fundamenta na perspectiva do autor de que "a História é parcial e é parcelar. É parcelar, porque conta uma parte apenas daquilo que aconteceu" (REIS, 1998, p. 57). Porém, essa releitura da história de seu país se constrói de maneira desvinculada de qualquer idealização da pátria.

A forma como o romance histórico é adotado por Saramago não é, portanto, convencional. Defendemos a tese de que suas obras romanescas seguem a linha denominada "metaficção historiográfica", conceituada por Linda Hutcheon:

Com esse termo, refiro-me àqueles romances famosos e populares que, ao mesmo tempo, são intensamente auto-reflexivos e mesmo assim, de maneira paradoxal, também se apropriam de acontecimentos e personagens históricos. $\mathrm{Na}$ maior parte dos trabalhos de crítica sobre o pós-modernismo, é a narrativa que tem constituído o principal foco de atenção. A metaficção historiográfica incorpora todos esses três domínios, ou seja, sua autoconsciência teórica sobre a história e a ficção como criações humanas (metaficção historiográfica) passa a ser a base para seu repensar e sua reelaboração das formas e dos conteúdos do passado. (HUTCHEON, 1991, p. 22)

$\mathrm{Na}$ esteira desse conceito, a categoria de romance metaficcional irá defender a ideia de que a verdade da história pode ser questionada pelas verdades da literatura, pois,

a verdade da história passa a ser plural e o romance se ocupa dos limites de toda e qualquer representação. Dessa forma, o valor da narrativa, seja ela histórica ou literária, está não apenas na verdade do que diz, mas também na consciência de que usa uma determinada forma para dizer essa verdade. A metaficção historiográfica coloca em primeiro plano a autoconsciência de que a história e a literatura são construções discursivas, motivo pelo qual é possível reescrever o passado como ficção e a ficção como passado. (CROSSON, 2005, p. 35)

A metaficção historiográfica, portanto, aproxima a História da narrativa ficcional, uma vez que utiliza métodos de composição semelhantes ao literário, pois, além de ambas 
serem fruto do pensamento e das reflexões humanas, que estão, por sua vez, passíveis de influências ideológicas, mesmo que a atividade, - no caso do historiador - pretenda manterse imune à manipulação ou intervenção do sistema de ideias daquele que a escreve.

Devemos, ainda, considerar o fato de que, mesmo que a história possua procedimentos distintos e científicos, as ruínas sobre as quais ela se ergue (artefatos, documentos escritos, vestígios arquitetônicos etc.) nada dizem sobre si mesmas, e é o homem o responsável por contextualizá-las em seu tempo e impetrar um significado a elas. Isso nos leva a refletir a respeito da proposição defendida por Linda Hutcheon de que tanto a história como a ficção almejam uma verdade, visto que

a metaficção historiográfica refuta os métodos naturais, ou de senso comum, para distinguir entre o fato histórico e a ficção. Ela recusa a visão de que apenas a história tem uma pretensão à verdade, por meio do questionamento da base dessa pretensão na historiografia e por meio da afirmação de que tanto a história como a ficção são discursos, construtos humanos, sistemas de significação, e é a partir dessa identidade que as duas obtêm sua principal pretensão à verdade. (HUTCHEON, 1991, p. 127)

A pensadora acrescenta que essa verdade é relativa para cada uma das áreas. No que concerne ao campo artístico, busca-se um conceito de verdade que dialogue com a perspectiva de discurso, pois

\begin{abstract}
para a verdade da arte, a realidade extrema é irrelevante. A arte cria sua própria realidade, em cujo interior a verdade e a perfeição da beleza constituem o infinito refinamento dela mesma. A história é muito diferente. É uma busca empírica de verdades extremas, e das verdades externas melhores, mais completas e mais profundas, numa relação de máxima correspondência com a realidade absoluta dos acontecimentos do passado. (FISCHER apud HUTCHEON, 1991, p. 146)
\end{abstract}

$\mathrm{Na}$ esteira da possibilidade de a arte fundar a sua própria realidade, a ficção tem o poder de construir esteticamente aquilo que ela projeta e, ao passo em que não almeja a verdade absoluta, transgride os espaços da realidade, sendo capaz, inclusive, de partir das verdades históricas, no sentido de ressignificá-las e de relativizá-las, oportunizando o emanar de uma outra versão desta história. Como resultado, "as obras desse tipo especulam abertamente sobre o deslocamento histórico e suas consequências ideológicas, sobre a forma como se escreve a respeito da 'realidade' do passado, sobre aquilo que constitui 'os fatos conhecidos' de qualquer acontecimento" (HUTCHEON, 1991, p. 128). 
Esse é o ponto de vista adotado por Saramago em seus romances, uma vez que sua "busca de verismo e do histórico fundamenta-se pelo desejo de transformação do romance num documento de uma era de convulsões e de modificações substanciais na sociedade portuguesa" (GOMES, 1993, p. 84).

\section{A história vista de baixo}

Essa nova configuração do romance histórico adotada pelo autor dialoga, ainda, com a nova forma de fazer história, inaugurada pela corrente da Nova História, que se preocupa com "a história vista de baixo, em outras palavras, com as opiniões das pessoas comuns e com sua experiência da mudança social” (BURKE, 1992, p. 13). A Nova História vem, portanto, instaurar outra maneira de se pensar a história.

Esse conceito está desvinculado do julgamento absolutista da oficialidade da história tradicional, já que "a base filosófica da nova história é a ideia de que a realidade é social ou culturalmente constituída” (BURKE, 1992, p. 11). Assim, a Nova História percebe o discurso historiográfico como uma construção, levando em consideração a hipótese de que o passado não pode ser resgatado integralmente.

Esse redimensionamento do olhar histórico nos leva a considerar o silêncio das vozes variadas e opostas, subalternizadas pelo discurso da história tradicional, fazendo emanar a "história-vista-de-baixo".

A Literatura, então, enquanto forma de materializar o real, carregado do sentimentalismo humano, assume a responsabilidade de ponderar, de forma fictícia, acerca desses hiatos deixados pela história tradicional, cumprindo o papel de propor significações para eles, versando não apenas sobre o aconteceu, mas pautando-se, principalmente, sobre o que poderia ter acontecido.

Partindo da premissa de que a história e a literatura são recriações do mundo, acreditamos que ambas estão fadadas ao ficcional, já que se constroem através da linguagem humana, que, por sua vez, não se desvincula da influência daquele que a escreve, como destacamos anteriormente. Porém, a literatura é privilegiada, por contar com a possibilidade de instaurar e subverter verdades nos limites da imaginação.

A forma de se construir o imaginário e de interpretá-lo é diferente nas duas vertentes, pois “a História tem para com esta recriação do mundo feito texto, uma condição: é preciso que tudo tenha acontecido. O 'como' é fruto das escolhas e estratégias ficcionais do 
historiador, mas é preciso que algo tenha realmente ocorrido” (PESAVENTO, 2003, p. 35). Assim, "as estratégias ficcionais do historiador estariam presentes na escolha, seleção e rejeição de materiais, organização de um enredo, escolha e uso de palavras e metáforas, desvendamento de sentidos implícitos” (PESAVENTO, 2003, p. 35).

O que temos, então, é que "o resultado final [...] é também uma forma que leva a fazer crer, antes do que comprovar de maneira absoluta. O resultado é sempre uma versão, a mais próxima possível, daquilo que teria, um dia, ocorrido!” (PESAVENTO, 2003, p. 36). Nesse sentido, a literatura, portanto, não pretende instituir verdades, porém, ao desautomatizar os hábitos de percepção do leitor, o faz pensar acerca dos dados utilizados para construir seu texto. A partir dessa linha de pensamento, o autor irá construir tramas que trazem à tona não só as versões da história que ficaram à margem da história tradicional e oficial, mas também criando textos povoados por uma nova versão das histórias arquiconhecidas.

No compêndio de romances escritos por Saramago que dialogam com fatos históricos e míticos, destacamos Manual de pintura e caligrafia (1977), que pretende refletir acerca do conceito de mímesis e de representação; o Memorial do convento (1982) que narra outra história da construção do convento de Mafra, pela ótica daqueles que foram silenciados pelo discurso da história tradicional (neste romance, além do evento histórico da construção do monumento de Mafra, temos também a presença de alguns personagens que povoam as páginas da história, como D. João V e sua esposa, o Padre Bartolomeu Lourenço de Gusmão e o pianista Domenico Scarlatti); já O Ano da morte de Ricardo Reis (1984) traz como ambientação a ditadura salazarista, a Guerra civil espanhola e os eventos que culminaram na segunda guerra mundial; por sua vez, História do cerco de Lisboa (1989) apresenta, de forma entrecruzada, a história de Raimundo Silva e uma outra versão da história do Cerco de Lisboa, pautada não nos registros oficiais da história tradicional, mas naquilo que poderia ter sido o desfecho da história do Cerco, caso os portugueses não tivessem contado com a ajuda dos cruzados na luta contra os muçulmanos. Por fim, temos O Evangelho segundo Jesus Cristo (1998) e Caim (2009) como os romances integrantes do catálogo das metaficções historiográficas do autor.

Enquanto os quatro primeiros romances citados trazem como tema central a história de Portugal, os outros dois se classificam de maneira mais completa como metaficção historiográfica. Isso se dá em função de estas obras se configurarem como releituras 
transfiguradoras, que problematizam e questionam as religiões de base judaico-cristã, enquanto sustentáculo da formação cultural, ética e moral do Ocidente.

\section{A dessacralização dos mitos bíblicos}

Saramago, recorrentemente, dialoga com os textos bíblicos, e, em algumas obras, essa intertextualidade se constrói a partir da paródia, o que traz para tais narrativas um tom transgressor e questionador. Essa paródia se constrói a partir de seu caráter histórico e do papel que as verdades instituídas pelos textos pertencentes à Bíblia passam a ser considerados, conforme se cristalizam em forma de verdades sagradas e absolutas, como inspirados, sendo, entretanto, tratadas por Saramago, em suas obras, como textos históricos ou mesmo míticos.

O principal dado que caracteriza tais romances, em especial o que pretendemos analisar, é o uso que o autor faz da Intertextualidade, relida a partir da perspectiva desenvolvida por Julia Kristeva, que percebe a escrita como um processo de subjetividade e comunicabilidade, considerando no processo de linguagem não só o sujeito, mas também o outro que está em contato com a escritura. Kristeva desenvolve essa percepção do processo linguístico da escrita literária a partir do pensamento de Mikhail Bakhtin acerca do dialogismo. Para ele,

a "palavra literária", isto é, a unidade mínima da estrutura literária não se congela num ponto, num sentido fixo; ao contrário, constitui um cruzamento de superfícies textuais, um diálogo entre diversas escrituras: a do escritor, do destinatário, do contexto atual ou anterior. $\mathrm{O}$ texto, portanto, situa-se na história e na sociedade. Estas, por sua vez, também constituem textos que o escritor lê e nas quais se insere ao reescrevê-las. A diacronia se transforma em sincronia, e à luz desta transformação, a história linear surge como uma abstração. O escritor participa da história mediante a transgressão dessa abstração, por meio da escritura-leitura; em outras palavras, da prática de uma estrutura significante em razão de, ou em oposição, a uma outra estrutura. (NITRINI, 2000, p. 159)

No cruzamento de tais superfícies textuais, a análise literária buscará avaliar as similitudes existentes entre o enunciado transformador e seu lugar de origem, assim como perceber de que forma o intertexto absorveu os dados dos quais se apropriou. Aplicando essa teoria em nosso trabalho, pretendemos refletir sobre a forma como Saramago se apropria dos dados bíblicos na obra em análise, discorrendo a respeito do resultado deste 
diálogo, no sentido de compreender se ele reafirma a leitura arquiconhecida de tais textos, ou se propõe uma percepção nova sobre eles.

Nesse sentido, Kristeva percebe que a noção de intertextualidade se aplica na intersecção da história e da cultura no texto literário; para a pesquisadora, "[o] texto está, pois, duplamente orientado: para o sistema significante no qual se produz [...] e para o processo social do qual participa enquanto discurso" (KRISTEVA, 1974, p. 12). Assim, o texto ocupa uma dupla dimensão significativa,

por um duplo jogo: na matéria da língua e na história social, o texto se instala no real que o engendra: ele faz parte do vasto processo do movimento material e histórico e não se limita - enquanto significado a seu autodescrever ou a se abismar numa fantasmática subjetivista. (KRISTEVA, 1974, p. 11)

Nossa análise segue o caminho proposto por Kristeva, ao passo que a obra em análise não se limita a reafirmar o sentido histórico disseminado pela leitura teológica dos textos bíblicos canônicos. Acrescentamos ainda que, na perspectiva de Kristeva,

o autor pode se servir da palavra de outrem, para nela inserir um sentido novo, conservando sempre o sentido que a palavra já possui. Resulta daí que a palavra adquire duas significações, que ela se torna ambivalente. Esta palavra ambivalente é, pois, o resultado da junção de dois sistemas de signos. (KRISTEVA, 1974, p. 72)

No processo de construção do romance saramaguiano, o autor tem o cuidado de partir dos textos bíblicos e das leituras cristalizadas sobre ele, para questioná-los e para possibilitar uma nova leitura sobre eles, baseada em dados linguísticos e históricos.

Historicamente, no âmbito do desenvolvimento da religião Cristã, foi aplicada aos textos bíblicos uma interpretação vinculada ao seu sentido sagrado, legitimada enquanto verdade suprema, mesmo essa interpretação de base teológica possuindo lacunas e incoerências que fogem ao sentido de realidade. Auerbach chama a atenção a respeito da intenção da leitura religiosa aplicada aos textos bíblicos. Segundo o estudioso:

A intenção religiosa condiciona uma exigência absoluta de verdade histórica. [...] A pretensão da Bíblia chega a ser tirânica; exclui qualquer outra pretensão. O mundo dos relatos das Sagradas Escrituras não se contenta com a pretensão de ser uma realidade historicamente verdadeira - pretende ser o único mundo verdadeiro, destinado ao domínio exclusivo. (AUERBACH, 2002, p. 11) 
As narrativas bíblicas, nesse sentido, desconsideram toda configuração de produção que determina os textos considerados sagrados pelas religiões de base judaico-cristã como sendo literários, sendo passíveis, então, de outra dimensão interpretativa. Essa abordagem do texto bíblico é fundamentada a partir da categorização do Cristianismo como uma religião histórica, “cujos dogmas primordiais se baseiam em acontecimentos” (BLOCH, 2001, p. 58). Saramago então,

realiza uma crítica aos textos tidos como verdade, como os da Bíblia. Por meio de um fato histórico - o bíblico - Saramago força o leitor a repensar o passado histórico da bíblia, ao ler sua ficção, e enfatiza, também, o caráter ficcional da história de Caim. Agindo assim, Saramago muda o olhar dos leitores, que passam a questionar a veracidade do texto sagrado tal como ele chega ao homem hoje, e percebem que ficção e história se equivalem enquanto construções narrativas. (SYLVESTRE, 2011, p. 47)

O autor transforma e relativiza a visão religiosa da leitura de tais textos, na tentativa de revelar aquilo que fora silenciado e colocado à margem da interpretação tida como oficial. Com isso, questiona a veracidade dos acontecimentos narrados, tendo em vista as narrativas bíblicas - mesmo pretendendo revelar uma verdade sagrada vinculada ao Deus do Judaísmo - como não sendo imunes à influência ideológica daqueles que a compuseram.

No que diz respeito à verdade dos fatos da vida de Jesus, narrados pelos evangelistas, Robert Alter defende que

mesmo que se admita a tendência de alguns especialistas contemporâneos a encontrar um núcleo histórico em muitas dessas narrativas, é evidente que [...] os autores bíblicos, escrevendo séculos depois dos supostos acontecimentos, dispunham de poucos dados históricos sobre os quais se basear. Não está claro até que ponto eles mesmos acreditavam que as tradições históricas herdadas correspondiam a fatos reais, mas, se a prudência nos impede de qualificar sua atividade como "invenção", ainda assim nos parece provável que tenham exercido uma boa dose de inventiva sobre os materiais que tinham à mão. O ponto central, contudo, é que as invenções e projeções imemoriais da tradição popular não bastam para constituir uma prosa de ficção, que depende da imaginação particularizante de um escritor individual. (ALTER, 2007, p. 71)

Observemos que a discussão proposta é válida, tendo em vista os autores bíblicos se declararem como arautos do Cristianismo responsáveis por disseminar e perpetuar a religião de Cristo entre todos os povos, tendo, portanto, vinculado a seus textos um caráter de ensinamento e exemplo a ser seguido, demonstrando, assim, o aspecto ideológico 
dogmatizador destes textos. Esta origem do texto bíblico impõe uma problemática difícil de ser solucionada ao trabalho dos historiadores, já que

uma coisa é, para a inquieta consciência que busca uma regra para si, fixar sua atitude em relação à religião católica, tal como é definida cotidianamente; outra coisa é, para o historiador, explicar o catolicismo do presente como um fato de observação. Indispensável, é claro, a uma correta percepção dos fenômenos religiosos atuais, o conhecimento de seus primórdios não basta para explicá-los. A fim de simplificar o problema, chegamos a renunciar a nos perguntar até que ponto, sob um nome que não mudou, a fé, em sua substância, permaneceu realmente imutável. Por mais intacta que suponhamos uma tradição, faltará sempre apresentar as razões de sua manutenção. (BLOCH, 2001, p. 58)

Apesar de o Cristianismo ser uma religião histórica baseada na existência concreta de um Messias e de sua ação no mundo, não se pode, cientificamente, desvincular o caráter histórico dos textos bíblicos de seu aspecto sagrado e imanente. É na convergência desses dois fatores que Saramago vem propor sua reflexão, no intuito de desenvolver o diálogo a respeito da manutenção da religiosidade de base judaico-cristã em fundamentos considerados históricos e comprováveis.

\section{Saramago pós-moderno: a transgressão das "verdades" históricas, míticas e religiosas}

José Saramago, como vimos, produz obras marcadas pelo rompimento com o modelo e a temática clássica dos romances que trazem em seu centro a narração e o debate de fatos importantes da história, denominados como "romances históricos", pois algumas das histórias contadas pelo narrador saramaguiano, apesar de terem como base dados e episódios históricos, míticos e religiosos, são construídas sob uma nova perspectiva, a dos párias, daqueles que permaneceram à margem do discurso da história tradicional, nomeados por Linda Hutcheon (1991), no âmbito dos estudos culturais pós-modernos, como "excêntricos", trazendo à tona, com isso, outra versão desses fatos.

Para realizar essa empreitada, Saramago parte da própria história, ao tecer um intertexto entre a história oficial e a história esquecida, silenciada, segredada e, por vezes, até imaginada - considerando-se o teor fictício do gênero romance. Logo, as leituras promovidas por Saramago acerca destes episódios não pretendem validar a interpretação arquiconhecida deles, almeja, ao contrário, questioná-las. Para tanto, o autor apropria-se dos eventos e das personagens históricas de forma transgressora, no intuito de desconstruir o discurso da 
história oficial/tradicional e cunhar outra versão para esses fatos, como nos referimos anteriormente.

O Evangelho Segundo Jesus Cristo, apesar de trazer para a narrativa personagens amplamente conhecidos na história da religiosidade e da cultura ocidental, conserva a opção pelos párias, pelos esquecidos ou injustiçados como núcleo central do romance. E mesmo os personagens arquiconhecidos, quando introduzidos na obra, são redimensionados, ganhando um aspecto outro daquele disseminado pelo Cristianismo.

Esse tipo de arquitetura dos personagens do evangelho saramaguiano, apesar de ter como base a intertextualidade com as fontes bíblicas, canônicas ou não, está pautado na transformação subversiva deles.

Um dos motivos que enquadram $O$ Evangelho segundo Jesus Cristo na categorização de Romance Dialógico é o fato de o narrador apresentar as cenas da narrativa de forma a permitir que os personagens construam os diálogos livremente, sem sua intromissão. $\mathrm{O}$ narrador, efetivamente, sai de cena, permitindo ao leitor arbitrar sua opinião de forma liberta, tendo em vista não ser influenciado por ele ou encaminhar os fatos para uma leitura determinada. Porém, é necessário destacar que o narrador saramaguiano não se distancia totalmente dos fatos, pelo contrário, quando sai de cena sempre deixa uma inquietude no leitor, através das intromissões que realiza, levando o leitor a pensar, a questionar esses fatos sob uma perspectiva do presente, mesmo quando a narrativa se ambienta em tempos históricos e míticos.

Essa postura, além de se opor à leitura dogmatizante feita pela Igreja acerca dos textos sagrados, possibilita o diálogo entre as personagens, garantindo a expressão de sua versão dos fatos ali narrados. No caso do romance em análise, essa liberdade dada às personagens faz com que elas questionem até mesmo dos desígnios divinos, como podemos perceber no seguinte diálogo entre Jesus e Maria de Magdala:

Maria de Magdala chorou com Jesus e disse-lhe, Tu não o quiseste, Pior é
isso, respondeu ele, e ela, como se desde o princípio conhecesse, por
inteiro, o que, aos poucos, temos vindo nós a ver e a ouvir, Deus é quem
traça os caminhos e manda os que por eles hão-de seguir, a ti escolheu-te
para que abrisses, em seu serviço, uma estrada entre as estradas, mas tu
por ela não andarás, e não construirás um templo, outros o construirão
sobre o teu sangue e as tuas entranhas, portanto melhor seria que
aceitasses com resignação o destino que Deus já ordenou e escreveu para
ti, pois todos os teus gestos estão previstos, as palavras que hás-de dizer
esperam-te nos sítios aonde terás de ir, aí estarão os coxos a quem darás 
pernas, os cegos a quem darás vista, os surdos a quem darás ouvidos, os mudos a quem darás voz, os mortos a quem poderias dar vida, Não tenho poder contra a morte, Nunca o experimentaste, Já, sim, mas a figueira não ressuscitou, $\mathrm{O}$ tempo, agora, é outro, tu estás obrigado a querer o que Deus quer, mas Deus não pode negar-te o que tu queiras, Que me liberte desta carga, não quero mais, Queres o impossível, meu Jesus, a única coisa que Deus verdadeiramente não pode, é não querer-se a si mesmo, Como o sabes tu, As mulheres têm uns outros modos de pensar, talvez seja por o nosso corpo ser diferente, deve ser isso, sim, deve ser isso. (SARAMAGO, 2005, p. 339)

Aqui, Maria de Magdala, além de dialogar em "pé de igualdade" com Jesus, demonstra uma sabedoria elevada à dele nessa ocasião, o que é, por sua vez, subversivo, pois o Messias sucumbe ao conforto e ao aconselhamento de uma prostituta, demonstrando, assim, a efetivação da polifonia do discurso saramaguiano. A personagem demonstra uma sabedoria que transcende o conhecimento dos fatos por parte de Jesus, ela tem acesso ao presente e ao passado.

Maria de Magdala é uma das personagens mais redimensionadas deste romance, uma vez que se desvincula do tratamento sexista destinado às mulheres nos textos bíblicos; passando, assim, a ser responsável pela construção do perfil feminino típico de Saramago, ou seja, corporificando a mulher forte, decidida, dona de seu destino, tão comum nas narrativas do autor.

O perfil de Maria de Magdala na obra de Saramago foi delineado a partir das várias facetas destinadas a ela no âmbito dos evangelhos canônicos e apócrifos. A proximidade entre Jesus e Maria Madalena se destaca nos evangelhos apócrifos, incomodando, inclusive, os apóstolos, como nos é possível perceber na seguinte passagem: "Numa ocasião Pedro queixou-se a Jesus: - Mestre, não podemos suportar Maria Madalena, ela nos tira todas as oportunidades de falar. A todo momento está perguntando e não nos deixa intervir. Jesus não deu muita importância a Pedro e continuou considerando Madalena como discípula preferida" (PIÑERO, 2002, p. 105).

A carga negativa vinculada à personagem Maria Madalena, desde os primórdios do Cristianismo, tem base na construção e interpretação misógina dos textos bíblicos feita pela Igreja, o que nos leva a considerar a personagem uma das figuras mais injustiçadas da Bíblia. A confusão dos episódios e das personagens, nesse caso, levou a figura dela a ser composta a partir da "síntese de três biografias, formando o tríplice rosto de Madalena - 
endemoninhada, pecadora e prostituta - que perdurou durante séculos entre leigos no assunto" (FERRAZ, 2012, p. 163).

Como já esclarecemos, Saramago bebe em diversas fontes para compor sua Maria de Magdala, o que acaba por oportunizar a elaboração de uma personagem plural, que dialoga de forma representativa com várias ideologias que a circundam. Esses textos fornecem informações que validam os aspectos mais polêmicos da personagem, como sua relação amorosa e sexual com Jesus, que tem como fonte o Evangelho apócrifo segundo Filipe, conforme aponta Piñero:

Um par de documentos que insinuam uma relação especial com Maria Madalena, e por um único tratado que a apresenta como "companheira" ou "cônjuge" de Jesus. Dos dois primeiros só podemos deduzir com certeza que Maria de Magdala era uma das discípulas favoritas do Mestre e um de seus interlocutores preferidos em diálogos de revelação. [...] O terceiro documento acrescenta: [...] "A companheira [de Cristo é Maria] a Madalena. [O Senhor amava Maria] mais que [a todos] os discípulos e a beijava na boca com frequência. (PIÑERO, 2002, p. 112)

Nessa passagem, é destacada a possibilidade de uma relação afetiva entre Jesus e Maria Madalena, chamada também de Magdala pelo autor. Uma das informações que levam os pesquisadores a crer na viabilidade de tal leitura é a descrição da proximidade entre ambos, presente também em Saramago. No texto do lusitano, Maria de Magdala incorpora por completo a função de companheira de Jesus, - destacada também nos textos bíblicos, apócrifos e canônicos -; estando sempre ao seu lado e aconselhando, diversas vezes, o suposto filho de Deus acerca das decisões que era obrigado a tomar, como podemos perceber na seguinte passagem: "Se eu não acreditasse em ti, não teria de viver contigo as coisas terríveis que te esperam, E como podes saber tu que me esperam coisas terríveis, Não sei nada de Deus, a não ser que tão assustadoras devem ser as suas preferências como os seus desprezos" (SARAMAGO, 2005, p. 257).

Outro fato polêmico que permeia a relação de Jesus e Maria Madalena é a suposta relação sexual mantida entre ambos. Em Saramago, há a efetivação de tal envolvimento, descrito em mais de uma passagem, de maneira completamente dessacralizada, como no seguinte trecho:

Maria de Magdala apareceu, nua. Nu estava também Jesus, como ela o deixara, [...] quando Maria se deitou ao lado dele, e, tomando-lhe as mãos, puxando-as para si, as fez passar, lentamente, por todo o seu corpo, os cabelos e o rosto, o pescoço, os ombros, os seios, que docemente 
comprimiu, o ventre, o umbigo, o púbis, onde se demorou, a enredar e a desenredar os dedos, o redondo das coxas macias, e, enquanto isto fazia, ia dizendo em voz baixa, quase num sussurro, Aprende, aprende o meu corpo. [...] E ele aí o tinha, o seu corpo, tenso, duro, erecto, e sobre ele estava, nua e magnífica, Maria de Magdala, que dizia, Calma, não te preocupes, não te movas, deixa que eu trate de ti, então sentiu que uma parte do seu corpo, essa, se sumira no corpo dela, que um anel de fogo o rodeava, indo e vindo, que um estremecimento o sacudia por dentro, como um peixe agitando-se, e que de súbito se escapava gritando, impossível, não pode ser, os peixes não gritam, ele, sim, era ele quem gritava, ao mesmo tempo que Maria, gemendo, deixava descair o seu corpo sobre o dele, indo beber-lhe da boca o grito, num sôfrego e ansioso beijo que desencadeou no corpo de Jesus um segundo e interminável frêmito. (SARAMAGO, 2005, p. 233-235)

Esse aspecto da vida sexual do nazareno potencializa a dimensão da importância de Maria de Magdala na narrativa. Tal proximidade entre eles é invejada até mesmo pelos apóstolos, uma vez que a companheira de Jesus demonstra uma cumplicidade não alcançada por estes em relação ao filho de Deus, como nos é possível perceber nessa passagem: “Já chegou, disse Jesus, e os amigos não compreenderam o que ele pretendia significar com tais palavras, só Maria de Magdala, mas essa sabia tudo” (SARAMAGO, 2005, p. 351). Essa cumplicidade está presente também nos textos bíblicos apócrifos: “os outros [discípulos] [...] perguntavam: 'Por que [tu a amas] mais do que a todos nós?' O Salvador respondeu: 'Por que não vos amaria tanto quanto a ela'?” (PIÑERO, 2002, p. 112).

Maria de Magdala representa, na obra do lusitano, muito mais que a companheira de Jesus, ela materializa a libertação das mulheres da misoginia bíblica, pois é colocada no mesmo nível que os apóstolos. Esta sua dedicação a Jesus é relida dos textos bíblicos e traz à tona uma questão silenciada durante muito tempo pela interpretação dogmática da Igreja: o equiparamento das mulheres na sociedade cristã inicial, principalmente no gnosticismo de base cristã, como esclarece Johnson:

Uma das razões pelas quais Maria ouvia com tanta atenção era que a religião que ele apresentava se diferenciava muito do judaísmo mosaico. As mulheres eram colocadas no centro junto com os homens, partilhando igualmente seus deveres e seus consolos. [...] Jesus foi o primeiro mestre da história mundial a demonstrar sua ansiedade para colocar as mulheres em pé de igualdade com os homens (JOHNSON, 2001, p. 97)

Esse feitio de Jesus é corporificado pelo nazareno de Saramago, pois ambos democratizam o acesso da mulher ao espaço religioso e social. Muitas são as passagens da 
obra de Saramago que comprovam a libertação e a imposição da presença do sexo feminino no domínio da história de Jesus.

Podemos citar rapidamente o fato da ausência de mulheres em seu julgamento e crucificação, sendo este fato considerado por Jonhson como determinante para a culpabilização de Jesus. O estudioso acredita que, caso as mulheres que passaram pela vida do nazareno estivessem presentes na ocasião, sua manifestação teria transmitido o grau de injustiça do ato. Saramago problematiza a validade da reflexão de Johnson ao incluir na ocasião do julgamento e da crucificação de Jesus as mulheres:

Atrás iam os discípulos e as mulheres, eles irados, elas soluçando, mas tanto era o que valiam os soluços dumas como a ira doutros, Que devemos fazer, perguntavam-se à boca pequena, saltar sobre os soldados e tentar libertar Jesus, morrendo talvez na luta, ou dispersar-nos antes que venha também ordem de prisão para nós, e como não eram capazes de escolher entre isto e aquilo, nada fizeram, e foram seguindo, a distância, o destacamento da tropa" (SARAMAGO, 2005, p. 261)

Aqui, o autor descreve não o que ocorreu, mas o que poderia ter acontecido, através do pensamento e da fala das mulheres, dialogando, assim, com a reflexão de Johnson. As mulheres, através da figura de Jesus, ganham voz e lugar, pois são assistidas pela misericórdia do nazareno, uma vez que "o que sabemos com certeza é que Jesus sempre defendeu as prostitutas contra os puritanos e que rompeu com todos os esquemas e tabus em sua relação com as mulheres, um ser que naquele tempo era totalmente desprezado" (ARIAS, 2001, p. $55)$.

Saramago faz uso, portanto, da abertura que a literatura tem em relação ao compromisso com a verdade, tão almejada pelos historiadores, para compor seu enredo, baseado naquilo que poderia ser e não necessariamente no que foi. A literatura cumpre, aqui, o papel de preencher as lacunas deixadas pela história, no sentido de propor uma reflexão do presente, através do rememoramento de suas origens. O autor adota esse método, nos parece, com o intuito de desmitificar fatos e símbolos da história do ocidente que foram cristalizados pelo tempo.

No que diz respeito à desconstrução dos mitos feita pelo autor, daqueles que compõem o ideário cultural português, e também dos que competem ao compêndio da tradição judaico-cristã, devemos considerar que

para Saramago, bem como para os escritores que adotam uma perspectiva "pós-moderna", o mito não passa de linguagem convencionalmente aceita 
por uma tradição para explicar algumas "verdades" que fundamentam determinada cultura, então, o papel do escritor, ao retomá-los seria refletir a respeito dos jogos de poder que alimentam a tradição dos mitos. (SYLVESTRE, 2011, p. 35)

Partindo dessa premissa, destacamos que o mito se vale da crença, logo, não pode ser comprovado cientificamente, ou mesmo empiricamente. Ele vem materializar o inconsciente, explicar e justificar os aspectos imanentes da existência humana, tendo em vista a impossibilidade de o homem conviver com a dúvida e com sua inadequação a alguns aspectos do mundo, principalmente no nível imanente, criando, assim, entidades maiores e mais poderosas para justificar essas questões incompatíveis com a realidade concreta e comprovável.

Aos poucos, a sacralidade vinculada ao mito vem sendo desconstruída, ao passo que as pesquisas atuais procuram investigar a origem e a justificativa da permanência deles, principalmente os religiosos, levando em conta o fato de que "ainda atuam na psique das pessoas, dominando o imaginário delas, embora tenham sua origem em tempos bastante remotos" (SYLVESTRE, 2011, p. 19). Esta proposição justifica a insistência de Saramago em trazer à tona a discussão acerca dos sustentáculos nos quais as religiões de tradição judaico-cristã foram construídas, questionando a verossimilhança e a posição sagrada destinada aos mitos, a partir dos quais construíram seus dogmas e preceitos.

É, portanto, no limite do simbólico que a literatura de Saramago atua, principalmente aquela que dialoga com os textos bíblicos e históricos, na busca do desvendamento das verdades escondidas por trás do discurso oficial da história e dos mitos. A leitura que o autor faz dessas histórias e mitos, por mais inquietantes e questionadoras que sejam, são fruto de sua visão e interpretação da vida, do homem e do mundo, permeadas por seu posicionamento pessoal e social, criando, assim, um mundo seu, que parece ser real, mas que não é.

A ficção proporciona a Saramago, portanto, a possibilidade de recontar a história, a partir de uma perspectiva estética. Nesse âmbito, ele dialoga com a categoria (possibilidade) de "subverter, virar do avesso" a história, adotando essa "atuação crítica" e irônica sobre os fatos, projetando "o imaginário sobre o real" e os relativizando, para, assim, transformar a realidade.

A escolha da temática religiosa judaico-cristã para enredar $O$ Evangelho segundo Jesus Cristo dialoga com o fato de a ideologia cristã ter influenciado, de forma efetiva e majoritária, 
a composição do ideário ocidental. Em suma, todos os preceitos morais e culturais ocidentais estão pautados nos dogmas judaico-cristãos. Essa premissa é reconhecida por Charles Bent, quando reflete acerca da religiosidade e do ideário moderno:

É inegável que o Cristianismo contribuiu grandemente para o desenvolvimento evolutivo da cultura ocidental. O espírito cristão e a compreensão cristã do homem, do mundo e de Deus foram incorporadas nas aspirações culturais e nas realizações do Ocidente. [...] muitos aspectos e características da cultura moderna ocidental seriam inconcebíveis fora da sua matriz cristã. (BENT, 1968, p. 17)

A participação do Cristianismo na formação da cultura ocidental é, portanto, inquestionável. Saramago é conhecedor desse fato, porém, retrata esse conceito de forma paródica, pois acredita na ineficiência atual da Igreja Católica e, consequentemente, dos dogmas e preceitos que mantém. Nos dias atuais, essa conjuntura dogmática e organizacional, mantida pelas igrejas de base judaico-cristã, encontra dificuldade em adequar-se à nova visão do homem e sua maneira de relacionar-se com o mundo moderno e pós-moderno.

Assim, ao retomar o texto bíblico, o autor reflete o propósito do desmantelamento da estrutura ética e moral da sociedade contemporânea, pois questiona seus princípios fundadores, tendo em vista que "a religião, o mito, e a arte assumem um papel fundamental, ao lado do conhecimento teórico-científico, de propiciar ao mundo uma interpretação de si mesmo. [...] Uma forma própria de entender o mundo que a própria modernidade produziu" (MAGALHÃES, 2000, p. 133).

\section{As várias vozes dos discursos de Saramago}

Além da linguagem intrínseca à escrita de Saramago, ganha destaque também, em sua obra, a forma como o autor constrói suas personagens, configuradas de maneira diversificada e elaboradas longe da influência dos estereótipos, ou seja, próximas da representação da multiplicidade da personalidade humana.

$\mathrm{Na}$ escolha de tais personagens, o que predomina não é a ordem das hierarquias sociais, como o foi comumente, ao longo da historiografia literária ocidental, mas sim a coerência com o mundo real, em que os seres de papel que participam das histórias são sujeitos reais, enfrentando situações grandiosas e factuais. O que vemos em suas obras, portanto, é a protagonização de sujeitos que sempre estiveram à margem dos discursos oficiais. 
É, portanto, por meio da classificação de seus romances enquanto polifônicos que essa possibilidade se abre, já que a polifonia pode ser compreendida como "a multiplicidade de vozes equipolentes, as quais expressam diferentes pontos de vista acerca de um mesmo assunto" (BAKHTIN, 2008, p. 4 e 38-9). "Essas vozes representam uma multiplicidade de consciências e seus mundos que se combinam numa unidade de acontecimentos" (BAKHTIN, 2008, p. 5), em nosso caso de análise, percebemos de que forma cada personagem bíblico se liberta da visão do outro sobre si e se torna protagonista do próprio discurso.

Assim, a particularidade da polifonia reside

no fato de que as vozes, aqui, permanecem independentes e, como tais, combinam-se numa unidade de ordem superior à homofonia. E se falarmos de vontade individual, então é precisamente na polifonia que ocorre a combinação de várias vontades individuais, realiza-se a saída de princípio para além dos limites de uma vontade. Poder-se-ia dizer assim: a vontade artística da polifonia é a vontade de combinação de muitas vontades, a vontade do acontecimento. (BAKHTIN, 2008, p. 23)

Ao projetarmos a manifestação dessas vontades individuais, combinadas na leitura que Saramago oportuniza dos episódios bíblicos do Novo Testamento, perceberemos emanar uma "vontade do acontecimento" que nos leva a uma visão humanizada das personagens, em especial de Jesus Cristo.

O referido método utilizado pelo autor revela a presença do dialogismo, que se configura como dado imanente em qualquer texto. Entretanto, a presença desse diálogo em comunhão com uma abordagem polifônica leva a narrativa a um tipo de representação dos sujeitos sociais mais próxima de sua pluralidade, uma vez que o narrador da história, que funciona como uma espécie de maestro, oportuniza a voz a todos os personagens da história, cada um embebido por uma carga ideológica que representa.

Percebemos nas obras de Saramago, enquanto atos de fala, a incorporação de elementos intertextuais e polifônicos que resultam na construção de um discurso dialógico. Ao se deparar com seu evangelho, é necessário que o leitor trave um diálogo intertextual com seu conhecimento pragmático-cultural, para que possa projetar a leitura proposta pelo autor, pois ele parte da nossa compreensão comum sobre os fatos e preceitos bíblicos para ressignificá-los. Sem a interação entre a obra e o leitor não há como alcançar resultados compreensivos desta obra, já que "reagimos àquelas (palavras) que despertam em nós ressonâncias ideológicas ou concernentes à vida" (BAKHTIN, 1992, p. 95). 
Nesse sentido, Bakhtin compreende o dialogismo como a condição para o sentido do discurso, este conceito está atrelado a um diálogo entre discursos e não entre indivíduos. O Dialogismo é, assim, o resultado do embate de muitas vozes sociais. E o romance, enquanto gênero polifônico por natureza se mostra como um projetor bastante significativo deste embate, uma vez que materializa, no mundo da obra, diversificadas representações sociais, que trazem consigo variadas concepções ideológicas, que irão travar discursos que massificam ou transgridem determinadas estruturas sociais. Exemplo disso, conforme já mencionamos, é a paródia Neotestamentária de Saramago, que traz à tona diversos discursos silenciados pela interpretação teológica de tais textos.

A forma como Saramago resolve dialogar intertextualmente com os textos bíblicos é através do uso da paródia, partindo do pressuposto de que "os procedimentos de transmissão das palavras alheias podem ir desde a literalidade direta" até a "deformação paródica premeditada", a "deturpação" (OLIVEIRA NETO, 2012, p. 178), o autor, além de parodiar os textos com os quais dialoga, ainda os deturpa, transgride-os e, em alguns casos, dessacraliza-os, como o faz em O Evangelho segundo Jesus Cristo.

Essa forma de composição da narrativa, desvinculada de qualquer caráter transcendente, justifica-se pelo uso do método alegórico moderno, desenvolvido por Walter Benjamin, enquanto revelação do que foi reprimido no ato da construção e disseminação dos mitos e das versões da história tradicional.

Esse uso da alegoria por Benjamin difere da forma utilizada pela leitura da interpretação bíblica, que, por sua vez, tratava a alegoria como forma de elucidar os textos considerados sagrados, construindo, assim, uma ponte abstrata entre o homem e Deus, entre o terreno e o espiritual.

Esse método utilizado pela Igreja é denominado Alegoria dos Teólogos, que, segundo João Adolfo Hansen, é “operada como hermenêutica [...], é uma técnica da interpretação que decifra significações tidas como verdades sagradas em coisas, homens, ações e eventos das Escrituras" (HANSEN, 2006, p. 91). Logo, enquanto técnica de interpretação,

é repetição incansável de um Significado que precede e preforma a história humana com sua Providência. Como "história natural da significação", para utilizar uma expressão de Walter Benjamin, a interpretação é redundante: ler é reler o mesmo em suas variações minuciosas, pois Deus é Causa e Coisa e a natureza e a história são seus efeitos e signos. Por isso, a hermenêutica lê os signos do texto bíblico segundo uma referência 
vertical, anafórica, cujo sentido é a Significação de todas as significações: Deus, a Graça, a Salvação. (HANSEN, 2006, p. 93-94)

As leituras dos textos bíblicos eram, portanto, pré-determinadas, pois dialogavam obrigatoriamente com a tendência sacralizadora deles, tidas como simbólicas e figurais, com interpretações cristalizadas pelo tempo e pelo dogmatismo de uma tradição judaico-cristã. Sendo assim,

cristãmente pensada, a alegorização funciona, portanto, como a memória de um saber que se ausentou: faz recordar esse vazio, figurando-o. Valorizando a anterioridade do que é Verdadeiro sobre o que é escrito, dito e vivido. Assim, ao lerem as Escrituras, os teólogos medievais o faziam preformados pelo Significado que buscavam nas coisas e homens dos textos. A interpretação se fazia como posfiguração, linguagem que cai depois, na ordem do tempo, do Significado eterno já dado. Para tanto, a figura efetuava a polissemia de um sentido, repartindo-o em níveis. [...]. A relação se dava entre a estrutura do léxico e Deus, de um lado, e a Natureza criada por Deus, do outro. (HANSEN, 2006, p. 108)

A alegoria medieval é, portanto, didática, centrada na figura e pretende tornar hegemônica a mensagem cristã, pois "não é convenção da expressão, mas expressão da convenção" (BENJAMIN, 2004, p. 197). Seu uso, no que diz respeito à interpretação dos textos bíblicos, funcionou, inicialmente, como método para leitura das Sagradas Escrituras, visando à ideia de que o mundo físico e as produções humanas são apenas reflexos do ideal espiritual. Nas palavras de Walter Benjamin, trata-se do "simbólico como expressão dos mistérios da religião" (BENJAMIN, 2004, p. 182).

No âmbito da alegoria, portanto, o símbolo relaciona-se à religião e à teologia, enquanto a alegoria, na perspectiva redimensionada de Benjamin, destina-se a desvendar o que o símbolo esconde. Nesse sentido, João Batista Pereira argumenta que

a alegoria didático-cristã se identifica com as ações empreendidas pelo Cristianismo para a conquista dos crentes, cuja vertente teológica se reportava a exegeses bíblicas privilegiando o sentido literal das Escrituras. Como artifício pedagógico, ela prima pela integração da religião com o cotidiano, sublimando uma intenção de converter o homem, a exemplo do que era proclamado nos autos medievais. (PEREIRA, 2013, p. 143) 
A leitura dos mitos bíblicos, realizada por Saramago, afasta-se dessa aplicabilidade da alegoria, ao assumir seu conceito benjaminiano, renegando, assim, o teor aurático ${ }^{2}$ da leitura doutrinadora aplicada pela Igreja aos textos que compõem a literatura judaico-cristã.

Para Benjamin, a alegoria é a manifestação do que fora reprimido, e é, antes de qualquer coisa, um "meio de recuperar outros ecos e versões de fatos petrificados pela história" (BENJAMIN apud PEREIRA, 2013, p. 151), tendo como principal função "valorar a arte, inserindo-a no curso do tempo histórico, revelando como os seus procedimentos desnudam as ruínas e escombros culturais que a atitude simbólica tende a ocultar, imaginando-as atemporais, como se portassem valores eternos, imutáveis e universais" (PEREIRA, 2013, p. 152). Essa perspectiva da interpretação dos mitos e da história é adotada por Saramago.

Podemos inferir, então, que as possibilidades emanadas das releituras feitas por José Saramago são, em sua maioria, libertadoras, instauradoras de novas verdades, pois "os discursos poéticos se caracterizam, em resumo, pela ambivalência intertextual interna que, graças à multiplicidade de vozes e leituras, substitui a verdade "universal", única e peremptória pelo diálogo de "verdades" textuais (contextuais) e históricas" (BARROS, 2003, p. 7). Essa substituição da verdade "universal" por diversas outras verdades textuais caracteriza as leituras feitas pelos escritos do autor a respeito de alguns episódios históricos e sagrados.

Porém, se faz importante destacar que, ao propor a releitura desses episódios históricos e bíblicos, Saramago não pretende converter ninguém ao ateísmo, ou mesmo invalidar e esvaziar os mitos fundadores do patriotismo ufanista de Portugal. Aspira, ao contrário, além de oferecer uma nova versão fictícia dos fatos considerados sagrados e "verdadeiros", questioná-los, através do uso da ironia, como o narrador d'O Evangelho Segundo Jesus Cristo deixa claro: "Sendo Jesus o evidente herói deste evangelho, que nunca teve o propósito desconsiderado de contrariar o que escreveram outros e, portanto, não ousara dizer que não aconteceu o que aconteceu, pondo no lugar de um Sim um Não" (SARAMAGO, 2005, p. 198).

\footnotetext{
${ }^{2} \mathrm{O}$ conceito de aura utilizado por nós diz respeito à definição dada ao termo por Walter Benjamin: "enquanto momento único de aparição de algo distante - o bic et nunc da fruição estética. É também o momento identificado pela ambição da obra em se apresentar como obra acabada, como dimensão simbólica de uma representação totalizante" (BENJAMIN, 1985, p. 185).
} 
A ironia presente neste trecho é evidente, pois nela o narrador dialoga com outra obra do autor, História do Cerco de Lisboa, que traz em seu enredo a descrição do que possivelmente poderia ter resultado do episódio histórico do Cerco de Lisboa caso os cruzados tivessem se recusado a auxiliar os portugueses na ocasião. Isso leva-nos a refletir, através de um processo de alusão, a respeito das possibilidades do que poderia ter ocorrido caso Jesus tivesse escolhido não se sacrificar pelo homem, já que o que percebemos no percurso do Jesus de Saramago é a constatação do fracasso anunciado de seu ato redentor, pois seu sacrifício não oportunizou o banimento da corrupção humana.

Saramago é, portanto, um irremediável parodiador dos textos fundadores de ideários culturais, sejam eles histórico-patrióticos ou religiosos, fazendo uso da palavra literária para desmistificar a versão/leitura oficial desses fatos, tendo em vista que o literário ilumina o que a ideologia não mostra, ele opera uma variação sobre a realidade, questiona o texto base; em suma, interroga a própria cultura.

Nesse percurso, o autor constrói uma ruptura com os textos que utiliza como base de alguns de seus escritos, como, por exemplo, os textos bíblicos, nos quais, através do método alegórico de reconstrução das ruínas, de apropriação de informações novas, descobertas históricas, arqueológicas, e da incorporação de outros textos desvendados e não incluídos no cânone bíblico - como os evangelhos apócrifos -, reconta a história da humanidade. Cada um desses campos oferta ao autor uma nova informação, não disponível à época de composição e construção da significação sagrada deles, possibilitando, assim, diversas outras leituras das narrativas contidas no Novo e no Velho Testamento do judaísmocristão.

Essas informações constituem-se como ruínas desses escritos, levando em consideração o sentido lato de ruína no âmbito alegórico, que consiste no

resto de um mundo que já foi e já se foi, aproxima-se do documento por não constituir-se a priori com a intenção de testemunhar propositalmente o passado (podendo fazê-lo a posteriori, quando transformada em monumento). Monumento, ruína - documentos unem-se como ruínas, índices do que foi, restos do pretérito, presentificados e presenteados a presentes posteriores. (KOTHE, 1986, p. 68)

Estas ruínas funcionam como testemunhas de um passado silenciado, conforme Benjamin esclarece. Elas contam a história do sofrimento neles sedimentado, ao recontextualizá-los em um novo encadeamento histórico, longe da conjuntura repressiva 
cotidiana à qual estão fadados pela interpretação da história tradicional, assim como, no caso da Bíblia, pela leitura mítica e sagrada dos teólogos. Deste modo, se a compreensão da história alegórica vê o mundo como ruína, é para

poder salvar os fragmentos, e se desenterra os mortos é para fazer-se atenta à sua súplica, enquanto a história simbólica é surda às alimentações dos oprimidos, e cega à estratégia dos opressores, que consiste em dissimular a realidade da história como fácies hippocratica, na qual se exprime tudo o que nela é "prematuro, sofrido e malogrado". (ROUANET, 1981, p. 20-25)

O texto saramaguiano, seguindo essa vazão que o uso das ruínas alegóricas proporciona, ao ressuscitar os discursos mortos pela dimensão aurática e simbólica dos textos bíblicos, alegoriza essas ruínas para compor seus evangelhos, com base em uma versão dos textos bíblicos pautados em uma interpretação daquilo que poderiam ser.

Ao aprofundarmos nossa análise da intertextualidade com os textos considerados sagrados pela tradição judaico-cristã, inicialmente, devemos considerar que aqueles que produziram os textos bíblicos eram, antes de tudo, escritores, tendo em vista que a Bíblia, além de ser educativa e informativa, serve também ao deleite, como nos lembra Robert Alter, n'A Arte da narrativa biblica (2007).

A Bíblia, então, segundo Alter (2007), exerce papéis distintos àquele doutrinador, comumente atribuído a ela, pois seus autores, assim como os escritores de uma maneira geral, entregaram-se aos prazeres da invenção e da expressão, a todos aqueles métodos fabulativos pertencentes à prosa de ficção. Esse aspecto inventivo, passível também às composições bíblicas, desvenda um caráter literário em tais textos.

Concomitante a isso, durante a leitura da obra saramaguiana, nos deparamos com a invalidação de algumas dessas interpretações fantásticas, através da explicação deles por meio da lógica, ou mesmo da ciência. Entretanto, não podemos deixar de considerar que a verossimilhança de tais fatos é pautada na fé religiosa. Além disso, o diálogo entre o fazer literário e a interpretação teológica e, portanto, sagrada, de tais textos é um fazer dinâmico.

Acerca dos elementos da narrativa bíblica, considerados por Saramago como fantásticos, nos é possível perceber um tom irônico, até mesmo ridicularizante, na voz da personagem Jesus Cristo d'O Evangelho segundo Jesus Cristo, quando discute com Deus a forma que utilizará para contar às histórias que irão auxiliá-lo na expansão dos limites de seu domínio, em suas palavras: "Devo-lhes contar histórias, então, Sim, histórias, parábolas, 
exemplos morais, mesmo que tenhas de torcer um bocadinho a lei, não te importes, é uma ousadia que as pessoas timoratas sempre apreciam nos outros" (SARAMAGO, 2005, p. 314315).

Logo, o acréscimo das ruínas, dos fragmentos, torna a leitura destes textos interessante e também vazada de possibilidades, já que "ao se estudar o passado, pode-se torná-lo iluminador do presente" (KOTHE, 1986, p. 50). Como exemplo, temos o fato de os personagens e, por vezes, o próprio narrador, não terem noção do futuro das histórias que estão sendo contadas, porém, o leitor detém esse poder, reconhecido pelo narrador de O Evangelho segundo Jesus Cristo:

ATRÁS DE TEMPO, TEMPO VEM [...] Não seria de todo crível que Jesus, na sua idade, andasse com estas palavras na boca, qualquer que fosse o sentido em que as usasse, mas nós, sim, que, como Deus, tudo sabemos do tempo que foi, é e há-de ser, nós podemos pronunciá-las, murmurá-las ou suspirá-las enquanto vamos vendo entregue à sua faina de pastor, por essas montanhas de Judá, ou descendo, no tempo próprio, ao vale do Jordão. (SARAMAGO, 2005, p. 198)

Nesse sentido, o autor não realiza uma releitura inaugural movida pelo ficcional e pelo fantástico, como comumente faz em suas obras, através do uso subversivo e fundante da metáfora; ele propõe, ao contrário, uma interpretação do Novo Testamento, a partir dos próprios textos sagrados.

Esse processo culmina na secularização desses escritos, em detrimento de sua histórica sacralização, como pontua Franco Crespi: “A desmitização do dogma e da moral realizada pela secularização, abre a possibilidade de uma aproximação ao texto sagrado através de uma interpretação pessoal, que Vattimo considera 'como o primeiro imperativo que a própria Escritura nos propõe”' (CRESPI, 1999, p. 60).

\section{Considerações Finais}

Após alcançarmos a finalização de nossa análise, chegamos ao ponto em que refletimos a respeito de como os procedimentos compósitos do evangelho de Saramago alcançam significações que rompem com a ideia aurática e canônica que tínhamos a respeito do tratamento impetrado aos textos bíblicos.

O uso da metaficção historiográfica nos auxilia a acessarmos pontos de vista inacessíveis, oportunizando, assim, o conhecimento de histórias silenciadas ou segredadas pelo discurso oficial da história e da religião. Isso se dá a partir da abordagem desses dados 
sob um novo ponto de vista vinculado às metodologias inauguradas pela Nova História e pelo método polifônico utilizado por Saramago na composição de suas obras.

A metaficção historiográfica, aliada ao discurso polifônico da obra, além do uso das ruínas alegóricas, nos leva a fundação de uma outra verdade, pautada nos limites da literatura, ou na falta deles. Uma verdade que, ao não pretender ser sagrada ou mesmo absoluta, vislumbra um outro caminho para a interpretação dos textos bíblicos, sejam eles canônicos, apócrifos/heréticos, ou mesmo gnósticos. Essa nova leitura proposta por Saramago nos induz a uma perspectiva humanista da história da passagem de Jesus pelo mundo. Nos revela um perfil revolucionário e questionador de um homem que não escolheu ser o Messias.

O evangelho de Saramago preenche lacunas deixadas pela interpretação teológica e pela escolha arbitrária do Canon bíblico, lacunas que só são possíveis de preencher a partir do uso irrestrito da imaginação. Porém, além de significar esses hiatos da história do nazareno, Saramago dessacraliza os episódios bíblicos arquiconhecidos, através da incorporação de dados intertextuais oriundos da história e de textos evangélicos ignorados pela Igreja.

O que há, portanto, nesta obra de Saramago, é o agenciamento da voz àqueles que foram silenciados e ignorados pelo discurso teológico oficial, revelando assim uma outra história de Jesus. Essa discussão nos leva a referenciar as matrizes sobre as quais nossa compreensão de mundo e de existência foi construída. A leitura desta obra, em especial, é dolorosa e reveladora, mas, ao mesmo tempo, transgressora e libertadora.

\section{BIBLIOGRAFIA}

ALTER, Robert. A arte da narrativa bíblica. Trad. Vera Pereira. - São Paulo: Companhia das Letras, 2007.

ARIAS, Juan. Jesus: esse grande desconhecido. Rio de Janeiro: Objetiva, 2001.

AUERBACH, Erich. Mimesis: A representação da realidade na literatura ocidental. $4^{\mathrm{a}}$ ed. São Paulo: Perspectiva, 2002.

BARROS, Diana Luz Pessoa. Dialogismo, Polifonia e Enunciação. In: BARROS, Diana Luz Pessoa de; FIORIN, José Luiz. (orgs.). Dialogismo, Polifonia, Intertextualidade: Em torno de Bakhtin. - 2. ed. - São Paulo: Edusp, 2003.

BAKHTIN, Mikhail. Marxismo e Filosofia da Linguagem. 6. ed. São Paulo: Hucitec, 1992. 
BAKHTIN, Mikhail. Problemas da poética de Dostoiévski. Tradução Paulo Bezerra. $4^{a}$ ed. Rio de Janeiro: Forense Universitária, 2008.

BENJAMIN, Walter. Origem do drama trágico alemão. Lisboa: Assirio \& Alvim, 2004.

BENT, Charles. Linha de Risco: O Movimento da Morte de Deus. Rio de Janeiro, RJ: Moraes Editores, 1968.

BLOCH, Marc Leopold Benjamin. Apologia da história, ou, O oficio do historiador. Rio de Janeiro: Jorge Zahar Ed, 2001.

BRAIT, Beth. As vozes bakhtinianas e o diálogo inconcluso. In: BARROS, Diana Luz Pessoa de; FIORIN, José Luiz. (orgs.). Dialogismo, Polifonia, Intertextualidade: Em torno de Bakhtin - 2. ed. - São Paulo: Edusp, 2003.

BURKE, Peter (org). A escrita da história: novas perspectivas. São Paulo: Editora da Unesp, 1992.

CRESPI, Franco. A Experiência religiosa na pós-modernidade. Bauru, SP: EDUSC, 1999.

CROSSON, Rildo. Romance Histórico: as ficções da história. Revista Itinerários, n. 23, Araraguara, p. 29-37, 2005. Disponível em < file:///C:/Users/Carol/Downloads/28046825-1-PB\%20(1).pdf> . Acessado em 28/06/2015.

FERRAZ, Salma. As faces de Deus na obra de um ateu: José Saramago. - 2. ed. ver. E ampl. - Blumenau: Edifurb, 2012.

GOMES, Álvaro Cardoso. A voz itinerante: Ensaio sobre o romance português contemporâneo. São Paulo: Editora da Universidade de São Paulo, 1993.

HANSEN, João Adolfo. Alegoria: construção e interpretação da metáfora. São Paulo: Editora Unicamp, 2006.

HUTCHEON, Linda. Poética do pós-modemismo: história, teoria, ficção. Tradução Ricardo Cmz - Rio de Janeiro: Imago Ed., 1991.

JOHNSON, Paul. Jesus: Uma biografia de Jesus Cristo para o século XXI. Rio de Janeiro: Nova Fronteira, 2001.

KOTHE, Flávio R. A Alegoria. São Paulo: Ática, 1986.

KRISTEVA, Julia. Introdução à Semanálise. Trad. Lúcia Helena França Ferraz. São Paulo: Perspectiva: 1974.

KRISTEVA, Julia. Semiótica do Romance. 2. ed. Trad. Fernando Cabral Martins. Lisboa: Arcádia, 1978. 
MAGALHÃES, Antonio. Deus no espelho das palavras: Teologia e Literatura em diálogo. São Paulo: Paulinas, 2000.

NITRINI, Sandra. Literatura Comparada: história teoria e crítica.2 ed. - São Paulo: Editora da Universidade de São Paulo, 2000.

OLIVEIRA NETO, Pedro Fernandes. Retratos para a construção do feminino na prosa de José Saramago. Curitiba: Appris, 2012.

PEREIRA, João Batista. Alegoria Benjaminiana. Revista FSA, Teresina, vol. 10, n. 3, art. 9, p. 137-158, Jul/Set. 2013.

PESAVENTO, Sandra Jatahy. O mundo como texto: leituras da História e da Literatura. Revista História da Educação, n. 14, Pelotas, p. 31-45, set. 2003.

PIÑERO, Antonio. O outro Jesus segundo os evangelhos apócrifos. São Paulo: Mercuryo, 2002.

REIS, Carlos. Diálogos com José Saramago. Editorial Caminho, SA, Lisboa - 1998.

ROUANET, Sérgio Paulo. Édipo e o anjo: Itinerários freudianos em Walter Benjamin. Rio de Janeiro: Tempo Brasileiro, 1981.

SARAMAGO, José. O Evangelho segundo Jesus Cristo. São Paulo: Companhia de Bolso, 2005.

SYLVESTRE, Fernanda Aquino. Diálogos entre a ficção e a história: o mito bíblico revisitado em Caim, de José Saramago. Revista Alere. Ano 04, Vol. 04. N. o 04, 2011. 